\title{
Circulating 25-hydroxycholecalciferol in Relationship to Central Dual-Energy X-Ray Absorptiometry Assesses

\author{
A clinical study
}

\begin{abstract}
DANA MARIA ALBULESCUㄹ, MARA CARSOTE²*, ADINA GHEMIGIAN², MIHAELA POPESCUㄹ, ANCA MIHAELA PREDESCUㄹ, MIHAELA J ANA TUCULINA², ADELINA SMARANDA BUGALA², MARILENA BATAIOSU², ROXANA IULIA MARINESCU², IONELA TEODORA DASCALU' ${ }^{1}$, MIHAELA STAN², CRISTIAN NIKY CUMPATA ${ }^{4}$, EDWIN SEVER BECHIR ${ }^{5}$

${ }^{1}$ University of Medicine and Pharmacy Craiova, Faculty of Medicine, 2-4 Petru Rares Str., 200349, Craiova, Romania

${ }^{2}$ Carol Davila University of Medicine and Pharmacy \& C.I. Parhon National Institute of Endocrinology, 34-38 Aviatorilor Av., Bucharest, Romania

3Medicine and Pharmacy University of Craiova, Faculty of Dental Medicine, 2-4 Petru Rares Str., 200349, Craiova, Romania ${ }^{4}$ Titu Maiorescu University, Dental Medicine Faculty, 67A Gheorghe Petrascu Str., 031593, Bucharest, Romania

${ }^{5}$ Medicine and Pharmacy University of Targu-Mures, Dental Medicine Faculty, 38 Gheorghe Marinescu Str, 540139, Targu Mures, Romania
\end{abstract}

The aim of the research was to realize a clinical study on menopausal patients, focused on 25-hydroxyvitamin D (250HD) assays versus Dual-Energy X-Ray Absorptiometry (DXA) categories. This transversal, observational, real-life study was effectuated on Caucasian Romanian females. A total of 60 subjects were grouped according to lumbar T-score: normal T-score $(N=28)$, osteopenia $(N=22)$, and osteoporosis $(N=10)$. The lowest average value of $250 \mathrm{HD}$ is found in patients with osteoporosis, which is statistically significant lower than in patients with osteopenia. The average values of PTH were within normal levels for each group. $250 H D$ did not correlate with PTH or lumbar BMD. Overall the mean values of $250 H D$ are in deficient ranges regardless osteoporosis, osteopenia or normal DXA.

Keywords: 25-hydroxycholecalciferol, vitamin D, bone, osteoporosis

Vitamin D represents a complex endocrine and biochemical system with multifunctional roles in humans (fig. 1) [1-3].

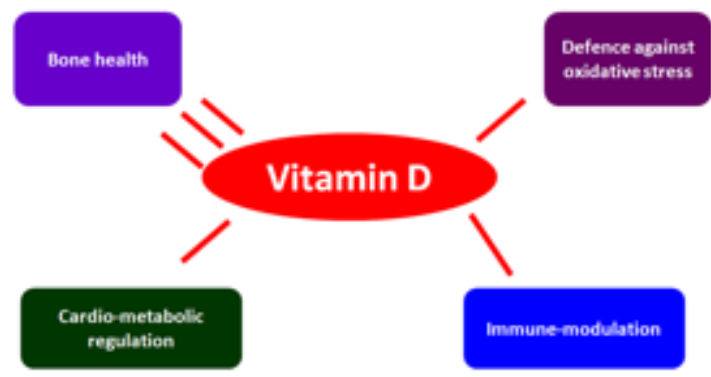

Fig.1. Vitamin D system: pathways of regulation

For instance, the first connected field involves skeletal health like adequate bone mineral density (BMD) for each age and sex, peak bone mass acquisition, prevention of osteomalacia, enhancement of the response to specific anti-osteoporotic drugs, direct contribution to periodontal and teeth well estate and, overall, the reduction of fragility fractures risk [4-8]. Vitamin D is mainly involved in different processes of skeletal health but also in immunemodulation, inflammation, regulation of oxidative stress reactions, and cardio-metabolic components function. Moreover, a part from skeletal involvement, the endocrine system of vitamin D is linked to inflammatory status, oxidative stress, metabolic anomalies like hypovitaminosis D - associated risk of high blood pressure, hyperlipemia, type 2 diabetes mellitus, metabolic syndrome; also almost 18 different types of cancer has been reported in association with vitamin D deficiency, etc. [9-12].
Vitamin D metabolism is a multiple enzymatic stepsbased system; the most important molecule for clinical evaluation in daily practice is 25 -hydroxyvitamin $D$ (25OHD) or $(6 R)-6-[(1 R, 3 a R, 4 E, 7 a R)-4-[(2 Z)-2-[(5 S)-5-$ Hydroxy-2-methylidene-cyclohexylidene] ethylidene]-7amethyl-2,3,3a,5,6,7-hexahydro- $1 \mathrm{H}$-inden-1-yl]-2-methylheptan-2-ol (also named calcifediol, calcidiol or 25hydroxycholecalciferol) (fig. 2) [13].

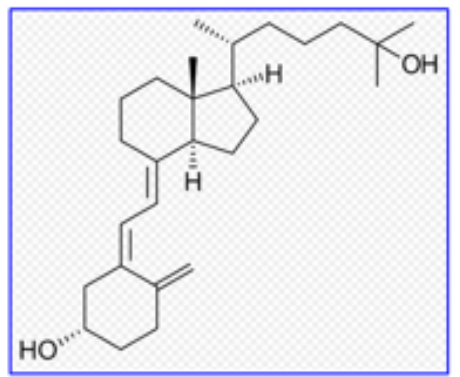

Fig.2. Biochemical structure of 25hydroxycholecalceferol [13]

The two major enzymes are hydroxylases and they act as follows: first cholecalciferol-25-hydroxylase converts cholecalciferol (vitamin $\mathrm{D}_{3}$ ) into $250 \mathrm{HD}$ at hepatic site. Then 250HD becomes a substrate for renal 25hydroxycholecalciferol-1 $\alpha$-hydroxylase which produces 1,25-dihydroxyvitamin $\mathrm{D}_{3}$ or $1,25(\mathrm{OH})$ D (also named calcitriol or 1,25-dihydroxycholecalciferol) [13]. The endocrine function of these biochemical structures is represented by the facts that $250 \mathrm{HD}$ is a pro-hormone or pre-hormone meaning an inactive form, with a binding affinity for nuclear vitamin D receptor of 1000 times less potent than active hormone while calcitriol is the actual active hormone; the 1- $\alpha$-hydroxylation of 250HD is also possible outside the kidneys, for instance, at the level of 
monocytes - macrophages system generating local 1,25 $(\mathrm{OH})_{2} \mathrm{D}$ with an autocrine role (fig. 3) [13-15].

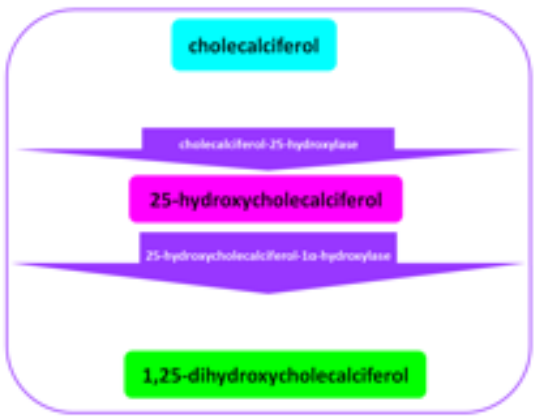

Fig.3. The most important biochemical steps included in vitamin D system

Blood levels of $250 \mathrm{HD}$ represent a major tool for assessment of vitamin D status in humans and current assays are for total 250HD (meaning free 250HD and molecules attached to transporter binding proteins, both albumin and globulin called vitamin D binding protein or VDBP) [16-18]. New data point the importance of switching to free component assessment (based on a immunoassay method) but this did not become a routine test yet [19-21].

We aim to introduce a clinical study on menopausal patients focusing on levels of 250HD in these patients depending on categories of risk indicated by DXA (DualEnergy X-Ray Absorptiometry) categories.

\section{Experimental part \\ Material and method}

The research is a real-life study transversal observational study on Caucasian Romanian females. The study was conducted between 2016 and 2017. The parameters are analysed at the end of data collection.

The studied characteristics of the patients were focused on prior and current skeleton status including fracture risk evaluation. The tools used are: anamnesis, physical examination - body mass index was calculated based on formula weight/(height) ${ }^{2}$, peripheral blood tests (fasting venous sampling) provided the results for $250 \mathrm{HD}$ (chemiluminescence kit), biochemical parameters -total (colorimetric, VITROS VITROS FS5.1) and ionic (colorimetric, COBAS C 501) serum calcium, phosphorus (colorimetric assay COBAS C 501), bone turnover markers for formation: alkaline phosphatase (colorimetric, VITROS FS5.1), osteocalcin (electrochemiluminescence), P1NP (ELLISA kit), for resorption: CrossLaps (electro- chemiluminescence), hormonal assays for parathormon (PTH, electro-chemiluminescence immunoassay).

The patients were enrolled in three groups based on DXA - BMD using as surrogate T-score (WHO groups: normal, osteopenia, and osteoporosis) (fig. 4) [22].

DXA data were provided by a GE Lunar Prodigy machine. Romanian FRAX (Fracture Risk Assessment Tool) was used based on free online calculator and 10-year probability of fracture was provided for four major osteoporotic fractures meaning clinical spine, forearm, hip, shoulder sites (R1), and also 10-year absolute risk of hip fracture (R2). The input parameters for R1 and R2 calculator are introduced in figure 5[23,24].

Numeric parameters are introduced as mean and standard deviation (SD), median, minimum and maximum. The parameters' database were introduced through Excel and exported in SPSS 21; statistical significant was considered at $p<0.05$; linear regression with different adjustments was also used.

The subjects were enrolled based on following inclusion criteria: menopausal Caucasian Romanian subjects with adequate data at lumbar DXA scan, informed consent, and exclusion criteria like active cancers, bone metastases, Paget's disease, haematological malignancies, prior diagnosis of osteoporosis, previous or current medication against osteoporosis or medication to reduce the fragility fracture risk (vitamin D and calcium supplements are not included), incomplete panel of bone parameters according to protocol, age below 41 years old, primary hyperparathyroidism.

\section{Results and discussions}

A total of 60 subjects were grouped according to lumbar DXA T-score: normal T-score $(\mathrm{N}=28$, Group NM), osteopenia ( $\mathrm{N}=22$, Group $\mathrm{OE})$, and osteoporosis $(\mathrm{N}=10$, Group OP) (table 1).

The patients' baseline parameters were introduced in table 2. The subjects with normal DXA were younger than those with osteoporosis (borderline statistical significance). The average age of menopause was between 47 and 48 years (similar according to lack of statistical significance between each two groups) while years since menopause varied between 11 and 15 years as mean values ( $p>0.05$ ). Subjects of lowest BMD group had also the low est BMI (statistical significant difference).

The levels of total/ionic calcium and phosphorus were similar between the groups. The levels of bone turnover

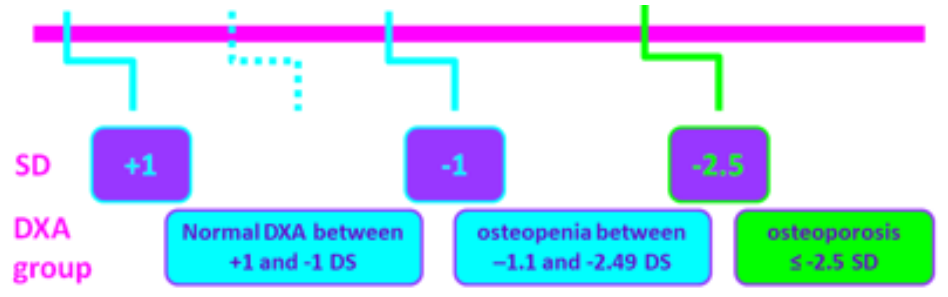

Fig.4. DXA groups according to WHO classification [22]

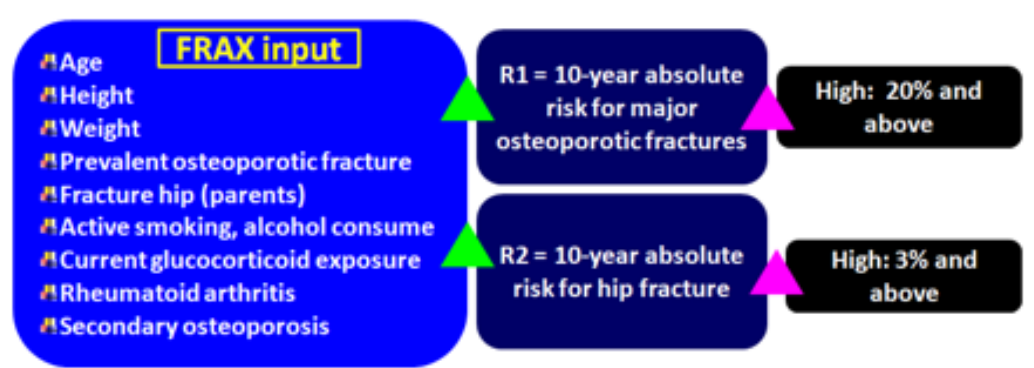

Fig. 5. FRAX algorithm inputs and outputs [23]
Table 1

THE STUDIED GROUPS OF MENOPAUSAL W OMEN WITHOUT PRIOR SPECIFIC THERAPY FOR OSTEOPOROSIS

\begin{tabular}{|c|c|c|}
\hline Group & $\begin{array}{c}\text { Number of } \\
\text { patients }\end{array}$ & T-score (DXA) \\
\hline NM & 28 & $+/-1 \mathrm{DS}$ \\
\hline OE & 22 & $\leq-1,>-2.5 \mathrm{DS}$ \\
\hline OP & 10 & $\leq-2.5 \mathrm{DS}$ \\
\hline
\end{tabular}




\begin{tabular}{|c|c|c|c|c|}
\hline Group & $\begin{array}{c}\text { Age } \\
\text { (years) }\end{array}$ & $\begin{array}{c}\text { Age of } \\
\text { menopause } \\
\text { (years) }\end{array}$ & $\begin{array}{l}\text { Years since } \\
\text { menopause }\end{array}$ & $\begin{array}{c}\text { BMI } \\
(\mathrm{kg} / \mathrm{sqm})\end{array}$ \\
\hline \multicolumn{5}{|c|}{ Group OP $(\mathrm{N}=10)$} \\
\hline mean & 63.6 & 48 & 15.6 & 25.33 \\
\hline median & 62 & 49.5 & 13.5 & 25 \\
\hline SD & 6.91 & 4.05 & 8.27 & 5.09 \\
\hline minimum & 51 & 40 & 2 & 18 \\
\hline maximum & 75 & 52 & 29 & 33 \\
\hline \multicolumn{5}{|c|}{ Group $\mathrm{OE}(\mathrm{N}=\mathbf{2 2})$} \\
\hline mean & 60.27 & 48.01 & 12.31 & 26.9 \\
\hline median & 58.5 & 49.5 & 10.5 & 26 \\
\hline $\mathrm{SD}$ & 6.78 & 5.39 & 9.44 & 5.04 \\
\hline minimum & 51 & 41 & 1 & 18 \\
\hline maximum & 77 & 57 & 35 & 35 \\
\hline \multicolumn{5}{|c|}{ Group NM (N=28) } \\
\hline mean & 58.5 & 47.11 & 11.62 & 29.87 \\
\hline median & 58 & 47 & 11 & 29 \\
\hline SD & 6.96 & 4.85 & 7.86 & 6.28 \\
\hline minimum & 45 & 41 & 2 & 21 \\
\hline maximum & 74 & 55 & 28 & 45 \\
\hline $\mathrm{p}$ value $\mathrm{OP}-\mathrm{OE}$ & 0.21 & 0.9 & 0.35 & 0.43 \\
\hline $\mathrm{p}$ value $\mathrm{OE}-\mathrm{NM}$ & 0.37 & 0.54 & 0.78 & 0.07 \\
\hline $\mathrm{p}$ value $\mathrm{OP}-\mathrm{NM}$ & 0.05 & 0.6 & 0.18 & 0.05 \\
\hline Group & $\begin{array}{c}\text { Alkaline } \\
\text { phosphatase } \\
\text { (U/L) }\end{array}$ & $\begin{array}{c}\text { CrossLaps } \\
\text { (ng/mL) }\end{array}$ & $\begin{array}{c}\text { Osteocalcin } \\
(\mathrm{ng} / \mathrm{mL})\end{array}$ & $\begin{array}{c}\text { PlNP } \\
(\mathrm{ng} / \mathrm{mL})\end{array}$ \\
\hline \multicolumn{5}{|c|}{ Group OP $(\mathrm{N}=10)$} \\
\hline mean & 78.77 & 0.57 & 28.49 & 58.28 \\
\hline median & 76 & 0.56 & 27.49 & 52.29 \\
\hline SD & 22.45 & 0.15 & 12.13 & 24.75 \\
\hline minimum & 44 & 0.29 & 11.37 & 29.5 \\
\hline maximum & 119 & 0.81 & 46.02 & 102.7 \\
\hline \multicolumn{5}{|c|}{ Group OE $(\mathrm{N}=\mathbf{2 2})$} \\
\hline mean & 92.24 & 0.54 & 27.74 & 63.6 \\
\hline median & 73.71 & 0.5 & 24.4 & 49.87 \\
\hline SD & 45.28 & 0.25 & 13.65 & 42.67 \\
\hline minimum & 47 & 0.24 & 14.77 & 31.99 \\
\hline maximum & 222 & 1.11 & 60.77 & 180.5 \\
\hline \multicolumn{5}{|c|}{ Group NM (N=28) } \\
\hline mean & 78.95 & 0.42 & 24.33 & 50.24 \\
\hline median & 78 & 0.36 & 24.89 & $\mathbf{4 7 . 4 3}$ \\
\hline SD & 18.57 & 0.2 & 11.53 & 19.75 \\
\hline minimum & 49 & 0.13 & 4.82 & 21.2 \\
\hline maximum & 112 & 0.185 & 56.26 & 93 \\
\hline $\mathrm{p}$ value $\mathrm{OP}-\mathrm{OE}$ & 0.41 & 0.8 & 0.88 & 0.76 \\
\hline $\mathrm{p}$ value $\mathrm{OE}-\mathrm{NM}$ & 0.22 & 0.08 & 0.36 & 0.26 \\
\hline $\mathrm{p}$ value $\mathrm{OP}-\mathrm{NM}$ & 0.98 & 0.07 & 0.36 & 0.4 \\
\hline
\end{tabular}

Table 2

THE STUDIED GROUPS: BASELINE PARAMETERS
Table 3

THE STUDIED GROUPS: BIOCHEMISTRY PANEL OF SPECIFIC INVESTIGATIONS FOR BONE TURNOVER MARKERS*

*normal levels for the following: alkaline phosphatase - 38-105 U/L, osteocalcin -

$15-46 \mathrm{ng} / \mathrm{mL}$, CrossLaps - $0.33-0.782 \mathrm{ng} / \mathrm{mL}$

markers are introduced in table 3 . The three groups have similar values (a difference with borderline significance was found for CrossLaps values between GROUP OE and $N M$, respective $O P$ and $N M$ ).

The blood levels of bone hormones 250HD and PTH are introduced in table 4. The lowest average value of $250 \mathrm{HD}$ is found in patients with osteoporosis which is statistically significant lower than $250 \mathrm{HD}$ on patients with osteopenia. Less than $10 \%$ of all subjects have secondary hyperparathyroidism. The average values of PTH were within normal levels for each group. 250HD did not correlate with PTH or lumbar BMD ( $p>0.05$ ).

BMD and T-scores as well as R1 and R2 are introduced in table 5. R1, respective $R 2$ were similar between each combination of two groups' regardless statistical significant difference between lumbar values provided by DXA of BMD, respective T-score.
As limits of the study we mention non-longitudinal, noninterventional data, the lack of routine profile X-Ray of the spine as typical screening method for prevalent vertebral fracture, and relative young age of the menopausal females (also taking into account the mean age of menopause and average period of time since menopause) which associates a relative low fracture risk. Prior studies on similar Romanian population of 50 years and older showed a 10year probability of major osteoporotic fracture of $5.3 \%$ and it increases to $13 \%$ in persons of 80 years old [25]. No particular pattern of risk regarding the combination of clinical risk factors was registered in studied population and it confirms the data from literature. $[26,27]$ As collateral observation we also introduce the idea that the prevalent biochemical levels of 250HD from this study represents a prior unselected population from the point of view of previous supplementation (and also similar observation is available for calcium supplements). We did 


\begin{tabular}{|c|c|c|}
\hline Group & $\begin{array}{c}\text { 25-hydroxyvitamin D } \\
\text { (25OHD) } \\
\mathrm{ng} / \mathrm{mL}^{*}\end{array}$ & 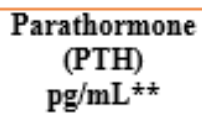 \\
\hline \multicolumn{3}{|c|}{ Group OP $(\mathrm{N}=10)$} \\
\hline mean & 13.99 & 63.93 \\
\hline median & 15.1 & 50.99 \\
\hline SD & 6.22 & 40.54 \\
\hline minimum & 3.98 & 24.53 \\
\hline maximum & 25.08 & 152.3 \\
\hline \multicolumn{3}{|c|}{ Group OE $(N=22)$} \\
\hline mean & 22.46 & 49.11 \\
\hline median & 22.95 & 51.01 \\
\hline SD & 9.35 & 16.54 \\
\hline minimum & 7.68 & 17.2 \\
\hline maximum & 43 & 77.39 \\
\hline \multicolumn{3}{|c|}{ Group NM (N=28) } \\
\hline mean & 19.34 & 51.07 \\
\hline median & 18 & 48.07 \\
\hline SD & 9.02 & 22.4 \\
\hline minimum & 5.15 & 30.1 \\
\hline maximum & 40.38 & 132.1 \\
\hline $\mathrm{p}$ value $\mathrm{OP}-\mathrm{OE}$ & 0.01 & 0.19 \\
\hline $\mathrm{p}$ value $\mathrm{OE}-\mathrm{NM}$ & 0.24 & 0.76 \\
\hline $\mathrm{p}$ value OP-NM & 0.09 & 0.24 \\
\hline
\end{tabular}

\begin{tabular}{|c|c|c|c|c|}
\hline Group & $\underset{(\mathrm{g} / \mathrm{sq} \mathrm{cm})}{\text { Lumbar }}$ & $\begin{array}{l}\text { Lumbar T-score } \\
\text { (SD) }\end{array}$ & $\begin{array}{l}\text { Rl-FRAX } \\
(\%)\end{array}$ & $\begin{array}{c}\text { R2-FRAX } \\
(\%)\end{array}$ \\
\hline \multicolumn{5}{|c|}{ Group OP $(\mathrm{N}=10)$} \\
\hline mean & 0.821 & -2.89 & 2.92 & 0.49 \\
\hline median & 0.856 & -2.7 & 2.3 & 0.25 \\
\hline SD & 0.077 & 0.54 & 1.29 & 0.46 \\
\hline minimum & 0.672 & -4.2 & 1.6 & 0.1 \\
\hline maximum & 0.879 & -2.5 & 5.4 & 1.4 \\
\hline \multicolumn{5}{|c|}{ Group $\mathrm{OE}(\mathrm{N}=\mathbf{2 2})$} \\
\hline mean & 0.985 & -1.57 & 3.83 & 0.9 \\
\hline median & 0.994 & -1.5 & 3.5 & 0.6 \\
\hline SD & 0.043 & 0.36 & 1.77 & 1.04 \\
\hline minimum & 0.882 & -2.4 & 1.9 & 0.1 \\
\hline maximum & 1.054 & -1.1 & 8.1 & 4 \\
\hline \multicolumn{5}{|c|}{ Group NM $(\mathrm{N}=28)$} \\
\hline mean & 1.2 & 0.182 & 5.35 & 1.62 \\
\hline median & 1.156 & -0.15 & 3.6 & 0.75 \\
\hline SD & 0.14 & 1.18 & 5.09 & 2.7 \\
\hline minimum & 1.055 & -1 & 2.1 & 0.2 \\
\hline maximum & 1.592 & 3.5 & 28 & 14 \\
\hline $\mathrm{p}$ value $\mathrm{OP}-\mathrm{OE}$ & 0.0001 & 0.0001 & 0.154 & 0.241 \\
\hline $\mathrm{p}$ value $\mathrm{OE}-\mathrm{NM}$ & 0.0001 & 0.0001 & 0.189 & 0.243 \\
\hline $\mathrm{p}$ value OP-NM & 0.0001 & 0.0001 & 0.147 & 0.198 \\
\hline
\end{tabular}

Table 4

THE THREE STUDIED GROUPS: BONE HORMONES VALUES 25OHD AND PTH not measure the pharmacological intervention of supplements which cannot be distinguished based on 250HD assays [28].

A general high prevalence of low 250HD in studied menopausal population which is characteristic for different European areas including for Romania confirmed the data from literature. [29-31] PTH levels were not correlated with PTH despite hypovitaminosis D despite the clear relationship of negative feedback between $250 \mathrm{HD}$ and PTH [32].

A similar Croatian study on 194 postmenopausal unselected women of 50 years old or older (average age of 60.6 years, with a mean menopause duration of 11.4 years) included $13.9 \%$ females with DXA confirmation of osteoporosis based on T-score, and a mean 250HD of almost $19 \mathrm{ng} / \mathrm{mL}$; also a statistical significant difference between $250 \mathrm{HD}$ values of menopausal group and normal
DXA group was identified [33]. Our data on European population with similar climate suggested the same results. These observations lead to the practical point that $250 \mathrm{HD}$ assays need to be carefully evaluated in osteoporotic patients who further need specific medication against osteoporosis in addition to vitamin D and calcium supplements. After the studies of Craciunescu et al [34], 25-OH-D level is an independent predictor of femoral neck $\mathrm{BMD}$ value and in cases with $25-\mathrm{OH}-\mathrm{D}$ values lower than $20 \mathrm{ng} / \mathrm{mL}$, urgent DXA evaluation is needed. The researches of [35] revealed that the inclusion of $25(\mathrm{OH}) \mathrm{D3}$ to an adipogenic differentiation cocktail significantly inhibited adipocyte differentiation at the concentrations of 25 and $2500 \mathrm{nmol} / \mathrm{L}$. The studies of Ene et al [36] consider that Vitamin $D$ deficiency correction might serve as a prevention approach for the progression of alopecia areata. The studies of Stoian et al [37] showed that serum ferritin 
levels were negatively associated with the presence of $25(\mathrm{OH})$ vitamin $\mathrm{D}$ deficiency in women and this association was independent of age, body composition. Large population studies are quoted in different guidelines of hypovitaminosis $D$ and reveal the conclusion that more than one half of non-responders to bisphosphonates actually associate inadequate low levels of 250HD as major cause of suboptimal response [38-40]. A secondary analysis from Aberdeen study (a randomized controlled trial) published in 2018 showed that in patients with low $250 H D$ the vitamin D supplementation directly improves BMD only in those adult subjects with baseline $250 \mathrm{HD}$ below $30 \mathrm{nmol} / \mathrm{L}$ (meaning $74 \mathrm{ng} / \mathrm{mL}$ ) [41]. When these data apply to our studied population all the subjects are below the mentioned threshold thus the become candidates to vitamin D supplementation. On the other hand, another study also published in 2018 showed that a direct correlation between long term serum 250HD and high BMD cannot be sustain in general healthy population [42].

\section{Conclusions}

Overall the mean values of $250 \mathrm{HD}$ are in deficient ranges regardless osteoporosis, osteopenia or normal DXA. A statistical significant lower level of serum $250 \mathrm{HD}$ is found in post-menopausal subjects with osteoporosis versus osteopenia.

\section{References}

1.WILLIAMS, NC, KILLER, SC, SVENDSEN, IS, J ONES, AW, Eur J Sport Sci. 2018, p. 1. doi: 10.1080/17461391.2018.1490458. [Epub ahead of print]

2.GOREY, S, CANAVAN, M, ROBINSON， S, O' KEEFFE, ST, MULKERRIN, E, QJ M, 2018. doi: 10.1093/qjmed/hcy126. [Epub ahead of print]

3.UMAR, M, SASTRY, KS, CHOUCHANE, Al, Int J Mol Sci., 19, no. 6, 2018. pii: E1618. doi: 10.3390/ijms19061618

4.THANDRAYEN, K, PETTIFOR, J M, Bone Rep., 8, 2018, p. 81 5.REID, IR, BOLLAND, MJ, GREY, A, Lance, 383, no. 9912, 2014, p. 146

6.FISCHER, V, HAFFNER-LUNTZER, M, AMLING, M, IGNATIUS, A, Eur Cell Mater., 35, no. 365, 2018, p. 365

7.DASCALU, IT, TUCULINA, MJ, RAESCU, M, POPESCU, SM, COREGA, C, VAIDA, L, BOLD, A, Rom. J. Morphol. Embryol., 54, no. 3 Suppl, 2013, p. 857-862

8.PREDA, SA, MORARU, I, RAESCU, M, BUNGET, A, NICOLA, A, GHEORGHITA, L, DASCALU, I, TUCULINA, M, ALBULESCU, DM, IANOVICI, N, Journal of Dental and Medical Sciences (IOSR-JDMS), 17, no. 6 Ver. 3, 2018, p. 89

9.POIANA, C, RADOI, V, CARSOTE, M, BILEZEKIAN, J, Bone Research, 1, no. 3, 2013, p. 260

10.MANSOURNIA, MA, OSTADMOHAMMADI, V, DOOSTI-IRANI, A, GHAYOUR-MOBARHAN, M, FERNS, G, AKBARI, H, GHADERI, A, TALARI, HR, ASEMI, Z, Horm Metab Res., 50, no. 6, 2018, p. 429 11.SANTOS, RKF, BRANDÃO-LIMA, PN, TETE, RMDD, FREIRE, ARS, PIRES, LV, Diabetes Metab Res Rev., 34, nr. 3, 2018. doi: 10.1002/ dmrr.2969.

12.JEON, SM, SHIN, EA, Exp Mol Med., 50, no. 4, 2018, p. 20

13.*** https://en.wikipedia.org/wiki/Calcifediol

14.CARLBERG, C, Front Endocrinol (Lausanne), 9, no. 250, 2018, doi: 10.3389/fendo.2018.00250.

15.CARLBERG, C, Mol Cell Endocrinol., 453, 2017, p. 14

16.SAIDA, FB, CHEN, X, TRAN, K, DOU, C, YUAN, C, Expert Rev Mol Diagn., 15, no. 3, 2015, p. 313

17.MALMSTROEM, S, REJ NMARK, L, IMBODEN, JB, SHOBACK, DM, BIKLE DD, J AOAC Int., 100, no. 5, 2017, p.1323
18.BIKLE, D, BOUILLON, R, THADHANI, R, SCHOENMAKERS, I, J Steroid Biochem Mol Biol., 173, 2017, p. 105

19.SU, Z, NARLA, SN, ZHU, Y. Clin Chim Acta, 433, 2014, p. 200

20.CARTER, GD, BERRY, J, DURAZO-ARVIZU, R, GUNTER, E, JONES, G, J ONES, J, MAKIN, HLJ, PATTNI, P, SEMPOS, CT, TW OMEY, P, WILLIAMS, EL, WISE, SA. J Steroid Biochem Mol Biol., 177, 2018, p. 30

21.COUCHMAN, L, MONIZ, CF, Ther Adv Musculoskelet Dis., 9, no. 4, 2017, p. 97

22.*** https://www.iofbonehealth.org/sites/d efault/files/PDFs/ Vertebral\%20Fracture\%20Initiative/IOF_VFI-Part_I-Manuscript.pdf

23.*** https://www.sheffield.ac.uk/FRĀX/

24.*** https://www.sheffield.ac.uk/FRAX/tool.aspx?country $=41$

25.GRIGORIE， D, SUCALIUC, A, JOHANSSON, H, KANIS, JA, MCCLOSKEY, E, Arch Osteoporos., 8, 2013, p.164

26.GRIGORIE， D, SUCALIUC, A, JOHANSSON, H, KANIS, JA, MCCLOSKEY, E, Calcif Tissue Int., 92, no. 5, 2013, p. 429

27. HANS, DB, KANIS, JA, BAIM, S, BILEZIKIAN, JP, BINKLEY, N, CAULEY, JA, COMPSTON, JE, COOPER, C, DAWSON-HUGHES, B, EL-HAJJ, FULEIHAN, G, LESLIE, WD, LEWIECKI, EM, LUCKEY, MM, MCCLOSKEY, EV, PAPAPOULOS, SE, POIANA, C, RIZZOLI, R; FRAX( $\left({ }^{\circ}\right)$ POSITION DEVELOPMENT CONFERENCE MEMBERS, J Clin Densitom., 14, no. 3, 2011, p. 171

28.ROSEN, CJ , N Engl J Med., 364, no. 3, 2011, p. 248

29.ALBU, SE, GELERIU, A, CARSOTE, M, MIHAI, A, VASILIU, C, POIANA, C, Archives of Balkan Medical Union, 50, no. 2, 2015, p. 275

30.HANSEN, KE, JOHNSON, MG, Curr Opin Endocrinol Diabetes Obes., 23, no. 6, 2016, p. 440

31.GALEANU, C, FLORESCU, A, UNGUREANU, MC, GROZAVU, I, LOGHIN, A, UNGUREANU, D, Rev Med Chir Soc Med Nat lasi, 118, no. 2, 2014, p. 327

32.CARSOTE, M, PADURARU, DN, NICA, AE, VALE, A, Journal of Medicine and Life, 4, no. 9, 2016, p. 348

33.LAKTASIC-ZERJAVIC, N, RUKAVINA, K, BABIC-NAGLIC, D, CURKOVIC, B, ANIC, B, SOLDO-JURESA, D, Reumatizam, 60, no. 1,2013, p. 8

34.CRACIUNESCU, M., STOIAN, D., SCHILLER, A., CRAINA, M., PETRE, I., BERNAD, E., ANDRICA, F., BORCAN, F., TIMAR, B., Rev.Chim. (Bucharest), 67, no.3, 2016, p. 543-548

35.PINZARIU, A.C., OBOROCEANU, T., ZUGUN ELOAE, F., HRISTOV, I., COSTAN, V.V., LABUSCA, L., CIANGA, P., VERESTIUC, L., HANGANU, B., CRAUCIUC, D.V., MANOILESCU, I,S., SINDILAR, E.V., MOCANU, V., Rev. Chim. (Bucharest), 69, no. 3, 2018, p. 731-734

36.ENE, C.D., CEAUSU, E., NICOLAE, I., TAMPA, M., MATEI, C., GEORGESCU, S.R., Rev. Chim. (Bucharest), 66, no.7, 2015, p.10681073

37.STOIAN, A.P., BALA, C., RUSU, A., SUCEVEANU, A., BADIU, D.C., NITIPIR, C., DITU, G., BICA, C., PADURARU, D.N., SERAFINCEANU, C., Rev. Chim. (Bucharest), 69, no. 4, 2018, p. 854-869

38.CIANFEROTTI, L, CRICELLI, C, KANIS, JA, NUTI, R, REGINSTER, JY, RINGE, JD, RIZZOLI, R, BRANDI, ML. Endocrine. 50, no. 1, 2015, p. 12

39.HOLICK, MF, BINKLEY, NC, BISCHOFF-FERRARI, HA, GORDON, CM, HANLEY, DA, HEANEY, RP, MURAD, MH, WEAVER, CM, Endocrine Society, J Clin Endocrinol Metab., 96, no. 7, 2011, p. 1911 40.ASPRAY, TJ, BOWRING, C, FRASER, W, GITTOES, N, JAVAID, MK, MACDONALD, H, PATEL, S, SELBY, P, TANNA, N, FRANCIS, RM, NATIONAL OSTEOPOROSIS SOCIETY, Age Ageing, 43, no. 5, 2014, p. 592

41.MACDONALD, HM, REID, IR, GAMBLE, GD, FRASER, WD, TANG, JC, W OOD, AD, J Bone Miner Res. 2018 Apr 17. doi: 10.1002/jbmr.3442. [Epub ahead of print]

42.LARSSON, SC, MELHUS, H, MICHAËLSSON, K, J Bone Miner Res., 33, no. 5, 2018, p. 840

Manuscript received:21.07.2018 